\title{
Dynamics of transmission of Plasmodium falciparum by Anopheles arabiensis and the molecular forms $M$ and $S$ of Anopheles gambiae in Dielmo, Senegal
}

\author{
Mamadou Ousmane Ndiath*1, Cécile Brengues², Lassana Konate ${ }^{3}$, \\ Cheikh Sokhna ${ }^{1}$, Christian Boudin ${ }^{1}$, Jean François Trape ${ }^{1}$ and \\ Didier Fontenille ${ }^{2}$
}

\begin{abstract}
Address: ${ }^{1}$ Institut de Recherche pour le Développement, Laboratoire de Paludologie et de Zoologie médicale, IRD Hann, BP 1386, Dakar, Sénégal, 2Institut de Recherche pour le Développement, UR016, B.P. 64501, 34397, Montpellier, France and 3'Université Cheikh Anta Diop de Dakar, BP 5005, Dakar, Sénégal

Email: Mamadou Ousmane Ndiath* - ndiatt@ird.sn; Cécile Brengues - cecile.brengue@mpl.ird.fr; Lassana Konate - konatela@yahoo.fr; Cheikh Sokhna - sokhna@ird.sn; Christian Boudin - boudin@wanadoo.fr; Jean François Trape - Trape@ird.sn;

Didier Fontenille - didier.fontenille@ird.fr

* Corresponding author
\end{abstract}

Published: 23 July 2008

Malaria Journal 2008, 7:136 doi:10.1 186/1475-2875-7-136

This article is available from: http://www.malariajournal.com/content/7////36

(C) 2008 Ndiath et al; licensee BioMed Central Ltd.

This is an Open Access article distributed under the terms of the Creative Commons Attribution License (http://creativecommons.org/licenses/by/2.0), which permits unrestricted use, distribution, and reproduction in any medium, provided the original work is properly cited.
Received: 21 November 2007

Accepted: 23 July 2008

\begin{abstract}
Background: The adaptation of Anopheles gambiae to humans and its environment involves an ongoing speciation process that can be best demonstrated by the existence of various chromosomal forms adapted to different environments and of two molecular forms known as incipient taxonomic units.
\end{abstract}

Methods: The aim of this study was to compare the epidemiologic role of Anopheles arabiens is and the molecular forms $\mathrm{M}$ and $\mathrm{S}$ of Anopheles gambiae in the transmission of Plasmodium in a rural areas of southern Senegal, Dielmo. The sampling of mosquitoes was carried out monthly between July and December 2004, during the rainy season, by human volunteers and pyrethrum spray catches.

Results: Anopheles arabiensis, An. gambiae $\mathrm{M}$ and $\mathrm{S}$ forms coexisted during the rainy season with a predominance of the $M$ form in September and the peak of density being observed in August for the $S$ form. Similar parity rates were observed in An. arabiensis [70.9\%] $(n=86)$, An. gambiae $M$ form [68.7\%] ( $n=64)$ and An. gambiae S form [8I.1\%] $(n=156)$. The circumsporozoite protein (CSP) rates were $2.82 \%(n=177), 3.17 \%(n=315)$ and $3.45 \%(n=405)$, with the mean anthropophilic rates being $71.4 \%(n=14), 86.3 \%(n=22)$ and $91.6 \%(n=24)$ respectively for An. arabiensis and An. gambiae $M$ and $S$ forms. No significant difference was observed either in host preference or in Plasmodium falciparum infection rates between sympatric $M$ and $S$ populations.

Conclusion: No difference was observed either in host preference or in Plasmodium falciparum infection rates between sympatric $M$ and $S$ populations, but they present different dynamics of population. These variations are probably attributable to different breeding conditions. 


\section{Background}

The Anopheles gambiae complex consists of at least seven species among which Anopheles gambiae s.s. is one of the most anthropophilic malaria vectors in Africa [1]. The adaptation of An. gambiae to humans and its environment involves an ongoing speciation process that can be best demonstrated by the existence of a number of incipient taxonomic units, characterized by the presence of paracentric inversions leading to different chromosomal arrangements [2]. This speciation process is primarily observed in West Africa, where five chromosomal forms of An. gambiae s.s. have been described and designated with a non-Linnean nomenclature: bamako, bissau, forest, mopti and savanna $[3,4]$.

During the last few years, several research teams have settled on a molecular approach to address speciation in $A n$. gambiae s.s.. Various degrees of gene flow restriction were demonstrated between chromosomal forms, with strong hybrid heterokaryotype deficits in the areas of sympatry. Analysis of the rDNA intergenic spacers, located on the Xchromosome, revealed fixed sequence differences between sympatric and synchronous savanna/bamako and mopti populations in Mali, Burkina Faso and Cameroon $[2,5,6]$. To provide more insight into their taxonomic status, recent efforts have focused on the pattern of variation observed with molecular markers. This revealed the existence of two genetic variants referred to as the molecular M and $\mathrm{S}$ forms $[7,8]$.

However, whatever the geographical region, it has been clearly demonstrated that the gene flow between $\mathrm{M}$ and $\mathrm{S}$ forms is very limited, revealing a current speciation phenomenon. The genetic characteristics of these forms and their known geographical distribution have recently been reviewed [9]. Studies carried out so far have shown that the $\mathrm{M}$ and $\mathrm{S}$ forms may have different habitat even in sympatric areas $[5,10]$.

The aim of this study was to compare the dynamics of transmission of Anopheles arabiensis and An. gambiae M and $\mathrm{S}$ molecular forms in a Senegalese village, where the two forms coexist.

\section{Methods \\ Study area}

The village of Dielmo $\left(13^{\circ} 45 \mathrm{~N}, 16^{\circ} 25 \mathrm{~W}\right)$ is located in an area of Sudan-type savanna, $280 \mathrm{~km}$ Southeast of Dakar and about $15 \mathrm{~km}$ north of the Gambian border. About 300 inhabitants are living in the village. Rainfall occurs during a four-month period, from June to October. The average annual rainfall during our study period in 2004 was $642.4 \mathrm{~mm}$. Dielmo is situated on the marshy bank of a small permanent stream, the Nema, where anopheline larval sites are present all year round. Only few cattle are living in this area [11].

\section{Mosquito collections}

Adult mosquitoes were collected monthly from July to December 2004. Two sampling methods were used: night landing catches (NLC) and pyrethrum spray catches (PSC). Hourly NLC were made on adult volunteers from 19.00 to 07.00 hours at the same two sites for three consecutive nights. Two collectors, one indoors and one outdoors, were positioned at each site. A total of twelve person-night of capture was done every month during the monthly collections. Six pyrethrum spray catches (PSC) was done during July to September early in the morning inside a total of twelve bedrooms, belonging to both types of houses, in different houses from those used for NLC.

\section{Field processing}

Anophelines were identified to species level using morphological characteristics according to the identification keys of Gillies \& De Meillon [12] and Gillies \& Coetzee [13]. Ovaries from a portion of females of An. gambiae s.l. captured on NLC were dissected to determine parity, by observing the degree of coiling of ovarian tracheoles [14]. A total of 50-60 were randomly selected monthly. All mosquitoes belonging to the An. gambiae complex, dissected or not, were stored in individual tubes with silicagel and preserved at $-20^{\circ} \mathrm{C}$ in the laboratory.

\section{Laboratory processing}

Bloodmeal sources of a sample of the females captured by PSC were tested by enzyme-linked immunosorbent assay (ELISA) to identify bovine, ovine, caprine (sheep and goat), equine (horse and donkey), or chicken hosts [15]. Malaria infections were determined on the crushed head and thorax of all anopheline specimens by ELISA using monoclonal antibodies against Plasmodium falciparum circumsporozoite protein (CSP), as described by Wirtz et al [16]: CSP rates and 95\% confidence intervals were calculated. Species identification of the An. gambiae complex was done by PCR [17]. Specimens identified as An. gambiae s.s. were tested for $\mathrm{M}$ and $\mathrm{S}$ molecular forms using the diagnostic PCR assay of Favia et al [2].

\section{Data analysis}

Parity, circumsporozoite protein and anthropophilic rates were estimated. Comparisons of these proportions between $\mathrm{M}$ and $\mathrm{S}$ molecular forms and the Hardy Weinberg equilibrium were performed by $\mathrm{X}^{2}$ test ( $\mathrm{P}$-values < 0.05 were considered to be statistically significant). The Human Biting Rate (HBR) was expressed as the average number of mosquito to bites per person per night during each month. The Entomological Inoculation Rate (EIR) was calculated by multiplying the (HBR) of each An. ara- 
biensis and An. gambiae $\mathrm{M}$ and $\mathrm{S}$ molecular forms by the respective CSP rate, for each month.

\section{Results \\ Species diversity}

A total of 1,109 An. gambiae s.l. were caught during 72 collection nights between July and December 2004 (889 by NLC and 220 by PSC). PCR for species identification was performed on 920 (83\%) mosquitoes belonging to the gambiae complex, resulting in $177 \mathrm{An}$. arabiensis, $316 \mathrm{An}$. gambiae molecular form M, 405 An. gambiae molecular form $\mathrm{S}$ and 22 hybrids $\mathrm{M} / \mathrm{S}$ (Table 1 ).

\section{Parity and anthropophily rate}

The mean parity rate was: $70.9 \%(\mathrm{n}=86)$, [CI: $60.1-80.2$ ] for An. arabiensis, 68.7\% ( $\mathrm{n}=64)$, [CI: 55.9-79.7] and $80.1 \%$ ( $\mathrm{n}=156)$, [CI: 73.0-86.1] for An. gambiae M and S forms, respectively. There was no significant difference between parity rates $\left(\mathrm{X}^{2}=4.3 ; \mathrm{p}=0.11\right)$. The proportion of mosquitoes fed on human was $71.4 \%(\mathrm{n}=14)$ [CI: 41.9-91.6], 86.3\% $(\mathrm{n}=22)$ [CI: 65.1-97.1] and 91.6\% (n = 24) [CI: 73.0-98.9], respectively, for An. arabiensis, An. gambiae $\mathrm{M}$ form and $\mathrm{S}$ form.

\section{Nocturnal biting cycle}

Details on hourly nocturnal biting cycle of the different species of An. gambiae s.l. are plotted in figure 1. HBR showed a consistent increased during night time reaching peaks between 11 p.m. and 5 a.m. depending on the species (Figure 1).

\section{Human biting rate}

An. gambiae S molecular form biting density was maximum in August (16.5 BPN), while the M molecular form was most abundant in September (17.6 BPN). An arabiensis, was less abundant and the maximum was recorded in August with 4.6 BPN (Figure 2).

\section{Circumsporozoite protein and entomological inoculation rate}

The results of CSP-ELISA assays are shown in Table 2. The mean CSP rate varied from $2.82 \%$ to $3.45 \%$, according to the species. The differences between infection rates were not signicant $\left(\mathrm{X}^{2}=0.16 ; \mathrm{p}=0.92\right)$. Among the hybrid species $\mathrm{M} / \mathrm{S}$ specimens, no CSP antigen was found. During this 6 months study period, the mean EIR was 70 infective bites/person. An. arabiensis and An. gambiae forms $\mathrm{M}$ and $S$ were responsible for $17 \%, 35 \%$ and $48 \%$ of $P$. falciparum transmission respectively.

\section{Hardy Weinberg equilibrium}

In total, 22 hybrids $\mathrm{M} / \mathrm{S}$ were obtained. The frequencies observed were 0.4 and 0.6 , respectively for the molecular forms $M$ and $S$. At the Hardy Weinberg equilibrium, the number of M/S hybrids expected was $366 \mathrm{M} / \mathrm{S}$ heterozygous. Difference highly significant $(\mathrm{p}<0.0001)$. The number of $\mathrm{M} / \mathrm{S}$ hybrids obtained was signicantly inferior in the case of panmictic crossbreeding.

\section{Discussion}

Anopheline densities varied during this study period. This strong variation is classical in savannah areas and is related to the presence of temporary ponds during the rainy season [16]. For An. arabiensis this phenomenon was well known in Dielmo $[1,18]$. The maximum biting rate by An. arabiensis, An. gambiae $\mathrm{M}$ and S forms occurred after 10 p.m., when most people are in bed, as generally observed throughout Africa [19]. The late biting behaviour of the more dangerous mosquitoes is a significant finding with respect to the increase use of insecticidetreated mosquitoes nets (ITN) for the reduction of malaria. The overall parity rate is comparable to that reported by Lemasson et al [20] in Senegal. This indicates that the population is long lived and has the capacity to be an efficient vector of malaria during a relatively long period. The high parity rate can partially explain the CSP rates of An. arabiensis and An. gambiae in the present study

Table I: Identification of the members of An. gambiae complex in Dielmo

\begin{tabular}{|c|c|c|c|c|c|c|c|c|}
\hline \multirow[t]{2}{*}{ Month } & \multicolumn{2}{|c|}{ An. arabiensis } & \multicolumn{2}{|c|}{$\begin{array}{l}\text { An. gambiae } M \\
\text { Form }\end{array}$} & \multicolumn{2}{|c|}{$\begin{array}{l}\text { An. gambiae } S \\
\text { Form }\end{array}$} & \multicolumn{2}{|c|}{ Hybrids M/S } \\
\hline & NLC & PSC & NLC & PSC & NLC & PSC & NLC & PSC \\
\hline July & 25 & 2 & 3 & 2 & 40 & 9 & 3 & 2 \\
\hline August & 52 & 4 & 53 & 8 & 198 & 13 & II & 0 \\
\hline September & 41 & 8 & 212 & 13 & 85 & 6 & 5 & I \\
\hline October & 12 & - & 22 & - & 34 & - & - & - \\
\hline November & 13 & - & 2 & - & 14 & - & - & - \\
\hline December & 20 & - & I & - & 6 & - & - & - \\
\hline Total & 163 & 14 & 293 & 23 & 377 & 28 & 19 & 3 \\
\hline
\end{tabular}

NLC $=$ Night landing catches

PSC $=$ Pyrethrum spray catches. 


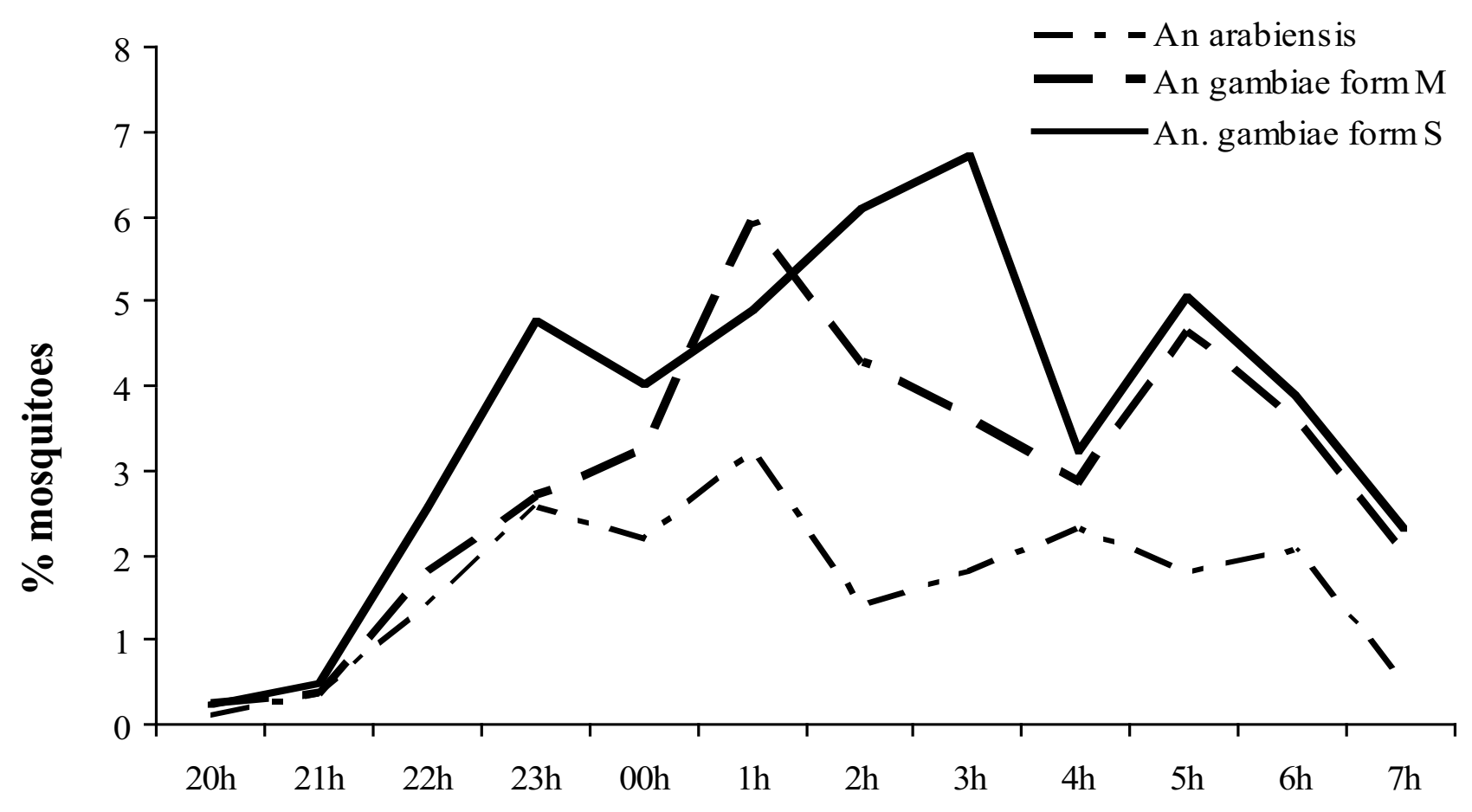

Figure I

The nocturnal biting cycle of An. arabiensis and An. gambiae M and S molecular forms, from July to December 2004, in Dielmo, Senegal.

which are greater than those previously recorded in other parts of Senegal $[1,18,20,21]$. The high CSP rate in An. arabiensis is probably explained by the high antropophilic behaviour in this particular setting. Highton et al [22] and Joshi et al [23] in the same region Kisumu, found high and similar CSP rate for An. gambiae s.s. (5.3\% and $7.5 \%$ respectively), while the CSP rate was very different for $A n$. arabiensis ( $0.3 \%$ and $7.5 \%$ respectively). The difference observed in An.arabiensis was due to cattle abundance and movements.

A recent analysis of published and unpublished data on the molecular forms of An. gambiae has demonstrated that the $\mathrm{M}$ form shows a more latitudinal range in West Africa than the S form, being the only form recorded in the Sahelien region of northern Senegal $[9,24]$. In Dielmo, the M form was mainly observed in rainy season from August to October, with a maximum in September. The S form was observed in the rainy season as well, with a maximum in August, but was also found during the dry season. An. arabiensis had an approximately constant density during the rainy season and the beginning of the dry season, without an obvious peak. Thus rainfall alone can not explain fluctuations observed in $\mathrm{M}$ and $\mathrm{S}$ forms densities.
Cytogenetic studies were conducted in 1991 in Dielmo and revealed an important chromosomic polymorphism. Thirty-two half-gravid females collected in January and February 1991 showed chromosomal inversions characteristic of bissau chromosomal form which belongs to the $\mathrm{M}$ molecular form [8]. Twenty-four females collected in September 1991 mainly revealed savanna cytotype which belongs either to $\mathrm{M}$ form or $\mathrm{S}$ form [8]. In this study, the replacement of $\mathrm{S}$ molecular form by $\mathrm{M}$ molecular form in the late rainy season might reflect the replacement of savanna chromosomal form by bissau chromosomal form. Climate (rainfall, temperature, relative humidity) as well as nature of anopheline larval development sites are dramatically change throughout the year during the rainy season. As chromosomal inversions are known to be involved in adaptation to climate and environment [1], the correspondence of molecular and chromosomal forms may explain the distribution pattern of molecular forms.

In West Africa, there is evidence of varying levels of hybridation between $M$ and $S$ forms, a mechanism by which adaptive genes may flow from one to the other, including those conferring insecticide resistance $[25,26]$. No, or very 


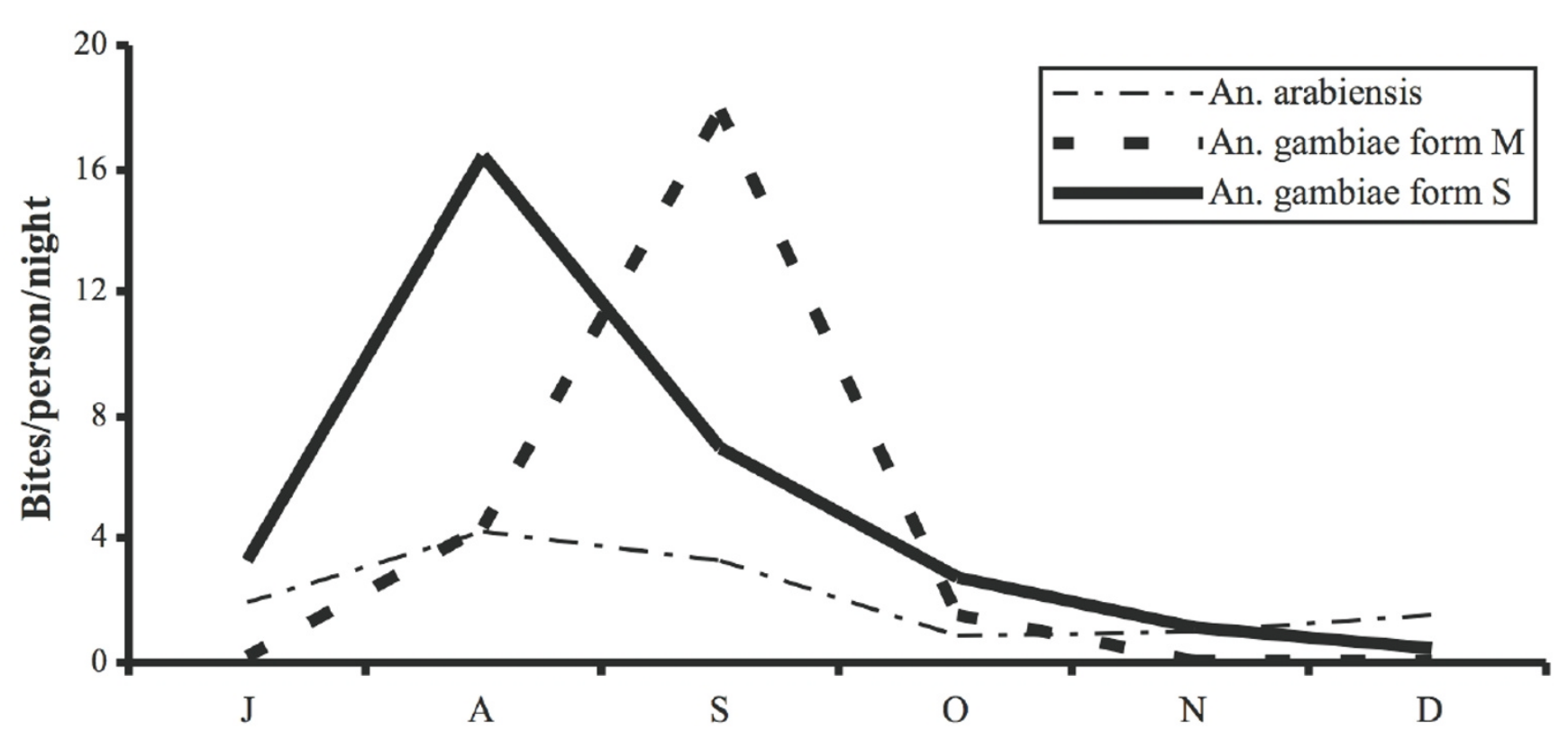

Figure 2

Monthly human biting rates of An. arabiensis and An. gambiae M and S molecular forms, from July to December 2004, in Dielmo, Senegal.

few, M/S hybrids were observed throughout Cameroon [6,27], Ghana [10], Mali and Burkina Faso [9]. In this study, $22 \mathrm{M} / \mathrm{S}$ hybrids were observed (3.05\%). Despite this number of hybrids, the An. gambiae population is far from Hardy Weinberg equilibrium suggesting restricted gene flow between $M$ and $S$ form. The occurrence of $M / S$ hybrids in the field, however, has been reported several times. Della Torre et al [8] found three hybrids patterns out of 1,161 An. gambiae adult mosquitoes tested from throughout Africa (hybrid frequency $=0.26 \%$ ). The authors, therefore, mentioned contamination as a possible cause of the hybrid patterns they reported. Further evidence for the viability of $\mathrm{M} / \mathrm{S}$ hybrids in the wild was provided by Taylor et al [28], who reported occurrence of $\mathrm{M} / \mathrm{S}$ hybrid larvae at a frequency of $0-1.29 \%$ in Banambani (Mali). Tripet et al [29] identified an inseminated female showing the M/S pattern, which demonstrated that $\mathrm{M} / \mathrm{S}$ hybrids could be produced in the field, survive up to the adult stage and are reproductively active.

\section{Conclusion}

Anopheles arabiensis and the $\mathrm{M}$ and $\mathrm{S}$ molecular forms of An. gambiae coexist in Dielmo village. No difference was observed either in host preference or in Plasmodium falciparum infection rates between sympatric $M$ and $S$ populations, but they present different dynamics of transmission: the $\mathrm{S}$ form is the major vector during the first part of the rainy season and is replaced by $M$ form later in the season. These variations are probably attributable to different breeding conditions.

Table 2: Infection rate for P. falciparum calculated by circumsporozoite protein (CSP) ELISA from the head and thoraxes of An. arabiensis, An. gambiae $M$ and $S$ forms in Dielmo

\begin{tabular}{|c|c|c|c|c|c|c|}
\hline \multirow[t]{2}{*}{ Month } & \multicolumn{2}{|c|}{ An. arabiensis } & \multicolumn{2}{|c|}{ An. gambiae M Form } & \multicolumn{2}{|c|}{ An. gambiae S Form } \\
\hline & Tested & Positive & Tested & Positive & Tested & Positive \\
\hline July & 27 & 2 & 4 & I & 49 & I \\
\hline August & 56 & I & 61 & 2 & 211 & 5 \\
\hline September & 49 & 0 & 225 & 4 & 91 & 5 \\
\hline October & 12 & I & 22 & 3 & 34 & 2 \\
\hline November & 13 & I & 2 & 0 & 14 & 1 \\
\hline December & 20 & 0 & 1 & 0 & 6 & 0 \\
\hline $\mathrm{CSP}$ rates $[95 \% \mathrm{cl}]$ & $2.82 \%[0.9-6.5]$ & & $3.17 \%[1.5-5.8]$ & & $3.45 \%[1.9-5.7]$ & \\
\hline
\end{tabular}




\section{Authors' contributions}

MON and DF have equally contributed to the design, acquisition, analysis, interpretation of data and manuscript drafting. LK contributed to conception of study and contributed markedly to the analysis of entomological data. CB for field activities and Molecular biology. JFT and $\mathrm{CB}$ participated in the conception and coordination of the study and helped to draft the manuscript. CS provided the scientific supervision in Dielmo.

\section{Acknowledgements}

We thank Charles Bouganali, Abdoulaye Gaye and Moise Gnafouna for their technical assistance, the villagers in Dielmo, Anna Cohuet for very helpful suggestions, and the DSF (Department support and formation of the south communities of IRD).

This work was supported by the programme Pal + programme of the French Ministry of Research and the Institute for Research and Development (IRD). This programme inclues three units of research: IRD-UR077 (Laboratoire de Paludologie Afrotropicale) - Dakar; UCAD (Université Cheikh Anta Diop) - Dakar and IRD-UR 016 (Laboratoire de Lutte contre les Insectes Nuisibles).

\section{References}

I. Coluzzi M: Spatial distribution of chromosomal inversions and speciation in Anopheline mosquitoes. Prog Clin Biol Res 1982, 96:143-153.

2. Favia G, Lanfrancotti A, Spanos L, Siden-Kiamos I, Louis C: Molecular characterization of ribosomal DNA polymorphisms discriminating among chromosomal forms of Anopheles gambiae s.s. Insect Mol Biol 200I, 10:19-23.

3. Coluzzi M, Petrarca V, Di Deco MA: Chromosomal inversion intergradation an incipient speciation in Anopheles gambiae. Boll Zool 1985, 52:45-63.

4. Toure YT, Petrarca V, Traore SF, Coulibaly A, Maiga HM, Sankare O, Sow M, Di Deco MA, Coluzzi M: The distribution and inversion polymorphism of chromosomally recognized taxa of the Anopheles gambiae complex in Mali, West Africa. Parassitologia 1998, 40:477-5।I.

5. Diabate A, Dabire RK, Kim EH, Dalton R, Millogo N, Baldet T, Simard F, Gimnig JE, Hawley WA, Lehmann T: Larval development of the molecular forms of Anopheles gambiae (Diptera: Culicidae) in different habitats: a transplantation experiment. J Med Ento$\mathrm{mol}$ 2005, 42:548-553.

6. Wondji C, Frederic S, Petrarca V, Etang J, Santolamazza F, Della Torre A, Fontenille D: Species and populations of the Anopheles gambiae complex in Cameroon with special emphasis on chromosomal and molecular forms of Anopheles gambiae s.s. J Med Entomol 2005, 42:998-1005.

7. Wondji C, Simard F, Fontenille D: Evidence for genetic differentiation between the molecular forms $M$ and $S$ within the Forest chromosomal form of Anopheles gambiae in an area of sympatry. Insect Mol Biol 2002, I I: I I-19.

8. Della Torre A, Fanello C, Akogbeto M, Dossou-yovo J, Favia G, Petrarca V, Coluzzi M: Molecular evidence of incipient speciation within Anopheles gambiae s.s. in West Africa. Insect Mol Biol 200I, 10:9-18.

9. Della Torre A, Tu Z, Petrarca V: On the distribution and genetic differentiation of Anopheles gambiae s.s. molecular forms. Insect Biochem Mol Biol 2005, 35:755-769.

10. Yawson AE, Weetman D, Wilson MD, Donnelly J: Ecological zones rather than molecular forms predict genetic differentiation in the malaria vector Anopheles gambiae s.s. in Ghana. Genetics 2007, |75:75|-76|.

II. Trape JF, Rogier C, Konate L, Diagne N, Bouganali H, Canque B, Legros F, Badji A, Ndiaye G, Ndiaye P, Brahimi K, Faye O, Druilhe P, da Silva LP: The Dielmo project: a longitudinal study of natural malaria infection and the mechanisms of protective immu- nity in a community living in a holoendemic area of Senegal. Am J Trop Med Hyg 1994, 51:I23-137.

12. Gillies MT, De Meillon D: The Anophelinae of Africa South of the Sahara. Publ South Afri Inst Med Res 1968, 54:343.

13. Gillies MT, Coetzee M: A supplement to the Anophelinae of Africa South of the Sahara, 2nd edn. Publ South Afri Inst Med Res 1987, 55: 143 .

14. Detinova TS, Gillies MT: Observations on the Determination of the Age Composition and Epidemiological Importance of Populations of Anopheles gambiae Giles and Anopheles funestus Giles in Tanganyika. Bull World Health Organ 1964, 30:23-28.

15. Fontenille D, Meunier JY, Nkondjio CA, Tchuinkam T: Use of circumsporozoite protein enzyme-linked immunosorbent assay compared with microscopic examination of salivary glands for calculation of malaria infectivity rates in mosquitoes (Diptera: Culicidae) from Cameroon. J Med Entomol 200I, 38:45।-454.

16. Wirtz RA, Ballou WR, Schneider I, Chedid L, Gross MJ, Young JF, Hollingdale M, Diggs CL, Hockmeyer WT: Plasmodium falciparum: immunogenicity of circumsporozoite protein constructs produced in Escherichia coli. Exp Parasitol 1987, 63:166-172.

17. Scott JA, Brogdon WG, Collins FH: Identification of single specimens of the Anopheles gambiae complex by the polymerase chain reaction. Am J Trop Med Hyg 1993, 49:520-529.

18. Fontenille D, Lochouarn L, Diatta M, Sokhna C, Dia I, Diagne N, Lemasson JJ, Ba K, Tall A, Rogier C, Trape JF: Four years' entomological study of the transmission of seasonal malaria in Senegal and the bionomics of Anopheles gambiae and Anopheles arabiensis. Trans $R$ Soc Trop Med Hyg 1997, 91 1:647-652.

19. Taye A, Hadis M, Adugna N, Tilahun D, Wirtz RA: Biting behavior and Plasmodium infection rates of Anopheles arabiensis from Sille, Ethiopia. Acta Trop 2006, 97:50-54.

20. Lemasson JJ, Fontenille D, Lochouarn L, Dia I, Simard F, Ba K, Diop A, Diatta M, Molez JF: Comparison of behavior and vector efficiency of Anopheles gambiae and Anopheles arabiensis (Diptera:Culicidae) in Barkedji, a Sahelian area of Senegal. J Med Entomol 1997, 34:396-403.

2I. Dia I, Diallo D, Duchemin JB, Ba Y, Konate L, Costantini C, Diallo M: Comparisons of human-landing catches and odor-baited entry traps for sampling malaria vectors in Senegal. J Med Entomol 2005, 42:104-109.

22. Highton RB, Bryan JH, Boreham PFL, Chandler JA: Studies on the sibling species Anopheles gambiae Giles and Anopheles arabiensis Patton (Diptera: Culicidae) in the Kisimu area, Kenya. Bull Ent Res 1979, 69:43-53.

23. Joshi GP, Service MW, Pradhan GD: A survey of species A and B of the Anopheles gambiae Giles complex in the Kisumu area of Kenya prior to insecticidal spraying with OMS-43 (Fenitrothion). Ann Trop Med Parasitol 1975, 69:91-104.

24. Carrara GC, Calzetta M, Santolamazza F, Di Deco MA, della Torre A, Petrarca V: Preliminary data on the distribution of species and forms of the Anopheles gambiae complex (Diptera: Culicidae) at sites of Angola. Parassitologia 2004, 46:85.

25. Fanello C, Santolamazza F, della Torre A: Simultaneous identification of species and molecular forms of the Anopheles gambiae complex by PCR-RFLP. Med Vet Entomol 2002, 16:46I-464.

26. Yawson AE, McCall PJ, Wilson MD, Donnelly MJ: Species abundance and insecticide resistance of Anopheles gambiae in selected areas of Ghana and Burkina Faso. Med Vet Entomol 2004, 18:372-377.

27. Favia G, della Torre A, Bagayoko M, Lanfrancotti A, Sagnon N, Toure YT, Coluzzi M: Molecular identification of sympatric chromosomal forms of Anopheles gambiae and further evidence of their reproductive isolation. Insect Mol Biol 1997, 6:377-383.

28. Taylor C, Toure YT, Carnahan J, Norris DE, Dolo G, Traore SF, Edillo FE, Lanzaro GC: Gene flow among populations of the malaria vector, Anopheles gambiae, in Mali, West Africa. Genetics 200I, 157:743-750.

29. Tripet F, Toure YT, Taylor CE, Norris DE, Dolo G, Lanzaro GC: DNA analysis of transferred sperm reveals significant levels of gene flow between molecular forms of Anopheles gambiae. Mol Ecol 200I, 10:1725-1732. 